\title{
Hot tearing in extruded brass for machining applications ${ }^{(\cdot)}$
}

\author{
R. Mannheim* and J. Garin*
}

\begin{abstract}
Hot tearing failure in $101-\mathrm{mm}$ rods in a direct $20 \mathrm{MN}$ Schlömann press was studied. After the fracture, a zone of fine tearing was observed in the area of the rods with the highest temperature. These fine cracks run in the direction of extrusion and obviously strongly reduced the air and water-tightness properties of the rods. The failure under study appeared in the last stage of solidification, in the temperature range close to the solidus line, which produces an insufficient capacity in the material to absorb tension. Lead condensation, which is the product of a heterogeneous distribution of temperature, is the source of the cracks observed in the rods. Nevertheless, the high temperature of the billet and the low ram speed of extrusion are the main parameters of the failure under study. To avoid this failure, the following is recommended: lower the temperature of the billet to between $660-680^{\circ} \mathrm{C}$ and increase the extrusion ram speed to $40 \mathrm{~mm} / \mathrm{sec}$. to reduce the extruded die-rod contact time.
\end{abstract}

Keywords Brass; Extrusion; Hot tearing; Failure.

\section{Fisuramiento en caliente en latón extruido para uso en mecanizado}

\begin{abstract}
Resumen
Se estudia la falla de fisuramiento en caliente en una barra de $101 \mathrm{~mm}$ de diámetro, extruida en una prensa directa Schlömann de 20 MN. Después de fracturar la barra se observan áreas de finos desgarros, en la zona de mayor temperatura de la barra. Estas finas grietas se desplazan paralelas a la dirección de extrusión y, obviamente, disminuyen fuertemente las propiedades de estanqueidad de las barras. La falla en estudio, aparece en la última fase de la solidificación, en el rango de temperatura cercana a la línea solidus, la cual produce una insuficiente capacidad del material para absorber las tensiones. La condensación del plomo, producto de una heterogénea distribución de temperatura, es la que origina las grietas observadas en la barra. No obstante, la elevada temperatura del billet y la baja velocidad de extrusión, son los principales parámetros que ocasionaron la falla en estudio. Para evitar esta falla, se recomienda lo siguiente: bajar la temperatura del billet entre $660-680^{\circ} \mathrm{C}$ y aumentar la velocidad de extrusión a 40 $\mathrm{mm} / \mathrm{s}$, como modo de disminuir el tiempo de extrusión en el contacto matriz-barra.
\end{abstract}

Palabras clave Latón; Extrusión; Fisuramiento en caliente; Falla.

\section{INTRODUCTION}

Lead-bearing brass rods are widely used in architecture, electronics and mainly as part of equipment. This alloy is used in bolts, screw, nuts, fittings and plates that are produced for machining processes. The content varies $\mathrm{Pb}$ between 2.5 and $3.5 \%$, which allows for machining processes at high speed with good surface aspect and low wear on tools. The main failure in the process have been studied in terms of the microstructure and mechanical characteristics of this alloy $\left.{ }^{[1} \mathrm{y} 2\right]$. This study does not include failure of air/water-tightness, which is important in employing lead to brass alloys for use with liquids and gases.
One important defect is hot tearing or hot shortness, or hot cracking. Irrespective of the name, this phenomenon represents the formation of an irreversible failure in the still semisolid casting. Although hot tearing is most often considered as a phenomenon linked to the inadequate compensation of solidification shrinkage by melt flow in the presence of thermal stress, there are more factors that could be involved in the formation of cracks at supersolidus temperature. Industrial and fundamental studies show that hot tearing occurs in late sages of solidification when the volume fraction of solid is above 85 to $95 \%$ and the solid phase is organized in a continuous network of grains. It's also known that a fine grain structure and

(•) Trabajo recibido el día 6 de febrero de 2009 y aceptado en su forma final el día 31 de marzo de 2009.

* Universidad of Santiago of Chile, Department of Metallurgical Engineering, Av. Bernardo O'Higgins 3363, Santiago of Chile. 
HOT TEARING IN EXTRUDED BRASS FOR MACHINING APPLICATIONS FISURAMIENTO EN CALIENTE EN LATÓN EXTRUIDO PARA USO EN MECANIZADO

controlled casting conditions (without large temperature and stress gradients) help to avoid hot cracking[3].

Thermomechanical processes are certainly among the most important methods to obtain final mechanical characteristics in plastically deformed products. The variables of the process to be considered are: the billet temperature, the die temperature, and the temperature of the container and the ram speed of extrusion. In lead to brass rods with a nominal radius of $101 \mathrm{~mm}$ and fractured in the rounded section, an area of fine cracks can be observed subsequent to the extrusion process. Nevertheless, it should be emphasized that the tearing observed after fracture does not appear in the case of a disk cut. These rods are produced in a $20 \mathrm{MN}$ Schlömann direct press.

In the context of this research, analysis was made using optical microscopy, scanning electron microscopy (SEM), and backscattering electron imaging (BEI) with energy dispersive spectrometry (EDS).

\section{EXPERIMENTAL PROCEDURE}

The chemical analysis was carried out with an optical emission spectrometer. The microstructure in the area of the failure was parallel and perpendicular to the direction of the extrusion. Grinding was done with $\mathrm{SiC}$ paper, with successive grinding and mechanical polishing. To reveal microstructure the rod was immersed in a solution of ferric chloride and hydrochloric acid[4]. SEM with secondary electrons was used to study the fracture and backscatter electron image, equipped with an EDS analyzer, was used to study the surface elements.

Hot extrusion conditions utilized in this work where: (a) press load capacity $2000 \mathrm{tn}$, (b) direct pressing, (c) billet length and diameter $720 \mathrm{~mm}$ and $203 \mathrm{~mm}$ respectively, (d) working temperature $720^{\circ} \mathrm{C}$, (e) extrusion ratio 4/1, (f) ram speed 17 $\mathrm{mm} / \mathrm{seg}$., (g) non lubrication.

\section{RESEARCH}

\subsection{Chemical analysis}

The chemical composition of the $101 \mathrm{~mm}$ rod was obtained with an optical emission spectrometer, see table 1 . The rod that fractured after extrusion can be observed in figure 1 .

\subsection{Optical microscopy}

On the other hand, the appearance of the surface tearing is shown in figure 2 in comparison with figure 3 , where normal surface is disclosed.

The micrograph in figure 4 shows the presence of three phases; alpha, beta and lead, in a view perpendicular to the direction of the extrusion. Anomalies in the microstructure do not appear in this image. In contrast, in figure 5 an area in the direction of the extrusion can be observed in which

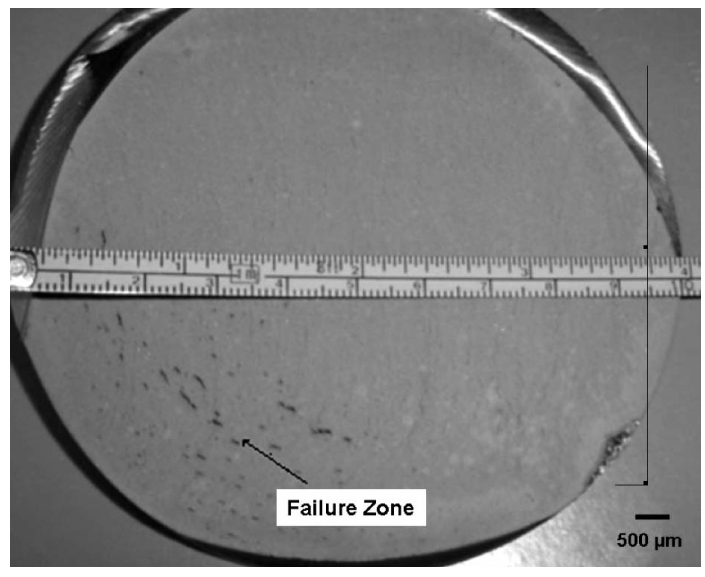

Figure 1. Fracture of the $101 \mathrm{~mm}$ diameter rod. The arrow indicates the area of cracking.

Figura 1. Fractura de la barra de $101 \mathrm{~mm}$ de diámetro. La flecha indica el área de fisuramiento.

Table I. Chemical composition of the rod $101 \mathrm{~mm}$ (wt, \%)

Tabla I. Composición química de la barra 101 mm (\% peso)

\begin{tabular}{lcccccccccc}
\hline \multicolumn{1}{c}{ Sample } & $\mathrm{Zn}$ & $\mathrm{Pb}$ & $\mathrm{Sn}$ & $\mathrm{Fe}$ & $\mathrm{Ni}$ & $\mathrm{Si}$ & $\mathrm{Al}$ & $\mathrm{Sb}$ & $\mathrm{Cu}$ & $\mathrm{Zneq}$ \\
\hline $\begin{array}{l}\text { rod } 101 \mathrm{~mm} \\
\text { brass rod EN }\end{array}$ & 36.89 & 2.88 & 0.30 & 0.24 & 0.083 & 0.003 & $<.001$ & 0.01 & 59.60 & 40.47 \\
12164 & $\mathrm{Bal}$ & $2.5-3.5$ & 0.3 máx. & 0.3 máx. 0.3 máx. & - & - & - & $57-59$ & - \\
\hline
\end{tabular}




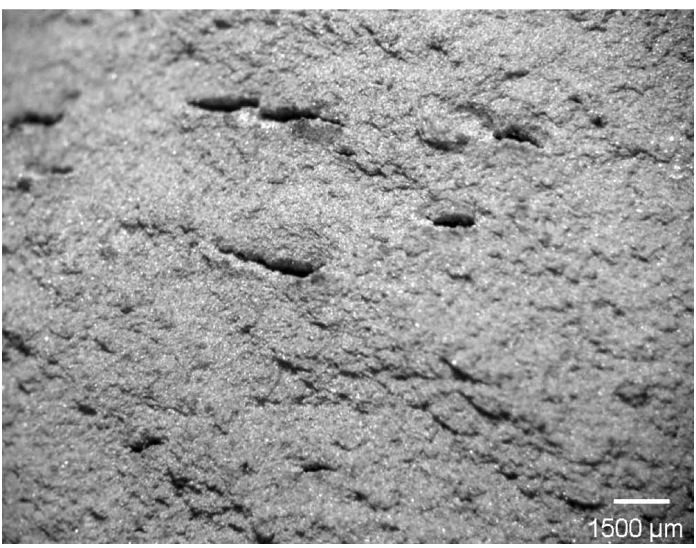

Figure 2. Fractography of the sample failure.

Figura 2. Fractografia de la muestra con falla.

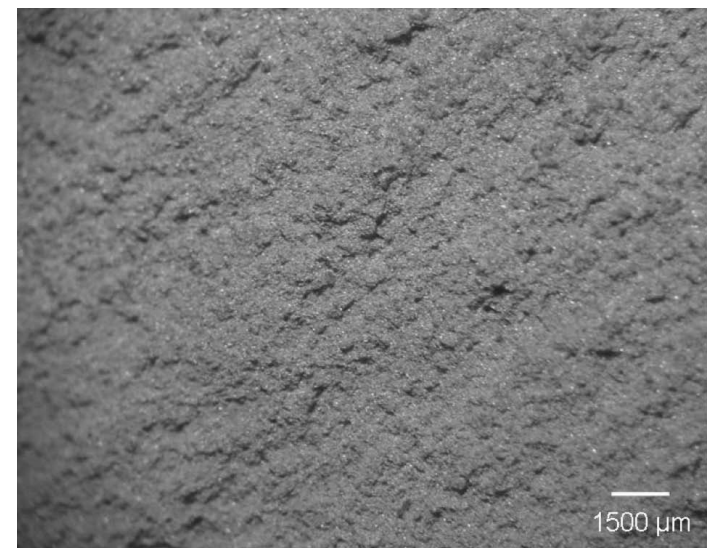

Figure 3. Fractography of the without hot tearing simple.

Figura 3. Fractografía de la muestra sin fisuramiento en caliente.

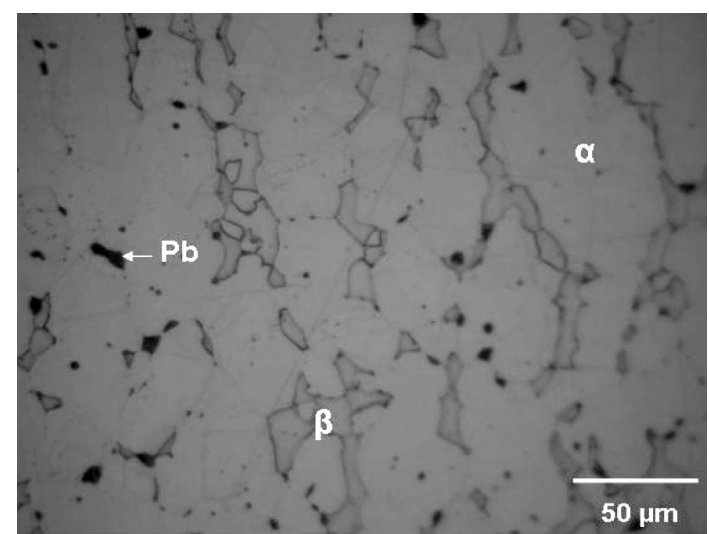

Figure 4. Micrograph of the rod perpendicular to the direction of the crack, 500x.

Figura 4. Micrografía de la barra perpendicular a la dirección de la grieta, 500x.

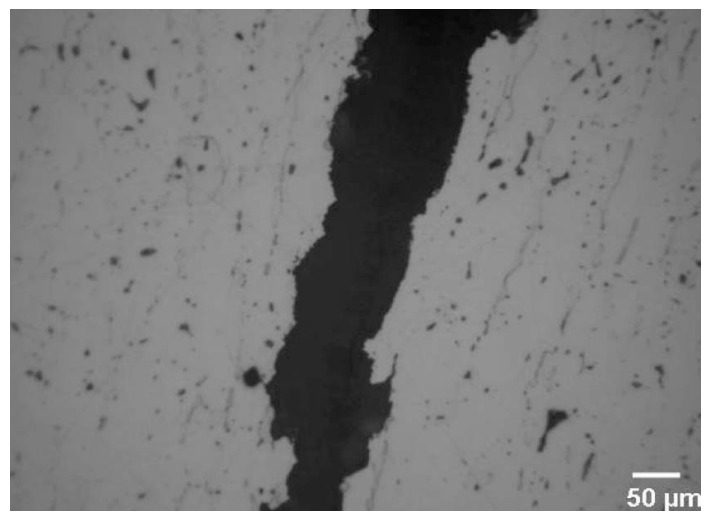

Figure 5. Micrograph of the rod parallel to the direction of the extrusion beginning of the crack, as polish.

Figura 5. Micrografía de la barra paralela a la dirección de extrusión, sin ataque.

it is possible to note the beginning of small tears that can subsequently be seen more clearly in the SEM micrograph.

In contrast, in figure 5 an area in the direction of the extrusion can be observed in which it is possible to note the beginning of small tears that can subsequently be seen more clearly in the SEM micrograph.

\subsection{Microscopic observation of the failure}

Figure 6 shows "shear intergranular cracks" that run in the direction of the extrusion and on the

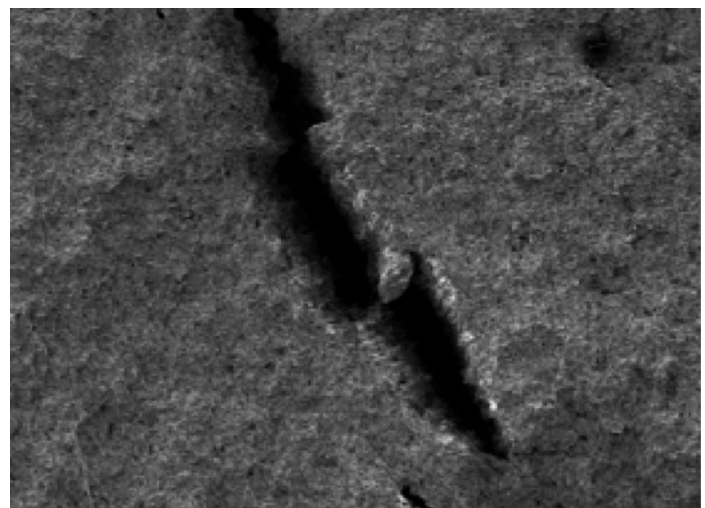

Figure 6. Area of tearing observed with SEM at $35 x$.

Figura 6. Área de fisuramiento observado con MEB a $35 x$. 
HOT TEARING IN EXTRUDED BRASS FOR MACHINING APPLICATIONS FISURAMIENTO EN CALIENTE EN LATÓN EXTRUIDO PARA USO EN MECANIZADO

fractured surface. Nevertheless, the crack is parallel to the direction of the extrusion and can be observed in $35 \mathrm{x}$ image.

Figure 7 shows numerous cracks running parallel to the direction of extrusion that naturally result in piece with low or no air/water-tightness. Figures 6 and 7 were made with scanning electron microscope, SEM.

\subsection{SEM/BEI fracture}

In figure 8 the surface topography with a magnification of 200x can be observed. In general, observation

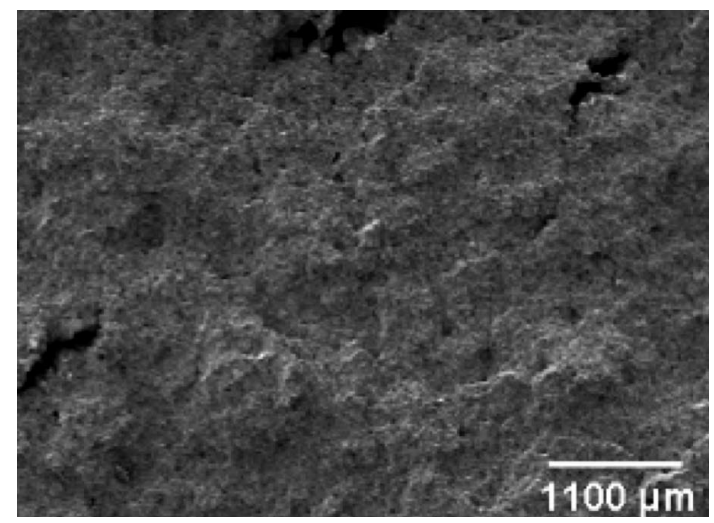

Figure 7. Area of secondary cracks with SEM at $35 x$.

Figura 7. Área de grietas secundarias observadas con MEB a 35x.

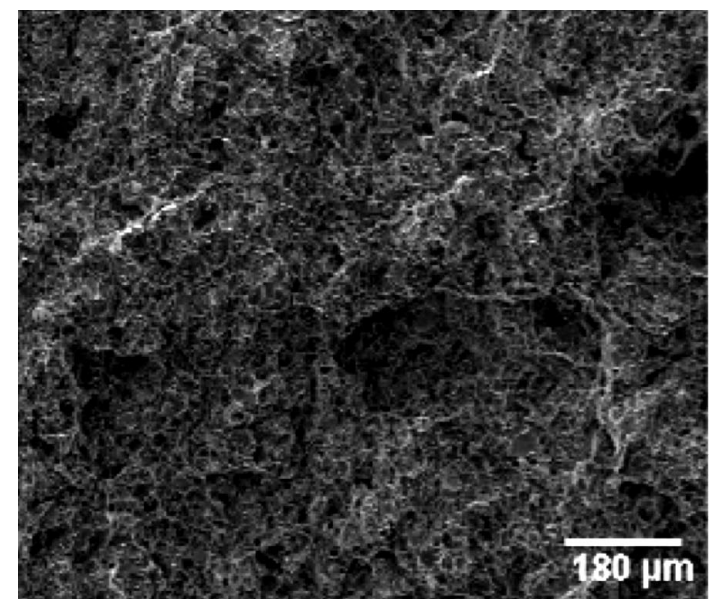

Figure 8. Fractography using SEM with secondary electrons at $200 x$.

Figure 8. Fractografía usando MEB con electrones secundarios a 200x. suggests that there is a fragile intergranular fracture, with the presence of numerous secondary microcracks (Fig. 7). In figure 9 the distribution of lead on the fractured surface can be observed, with a resolution of $200 x$, this micrograph was done by BEI. It can be noted in figure 9 that the areas of lead are condensed in certain points, the aforementioned effect is made evident observing figures 10 and 11 at $1000 x$. Figure 12 shows with greater clarity the tearing of the fragile fracture in one of innumerable secondary cracks of

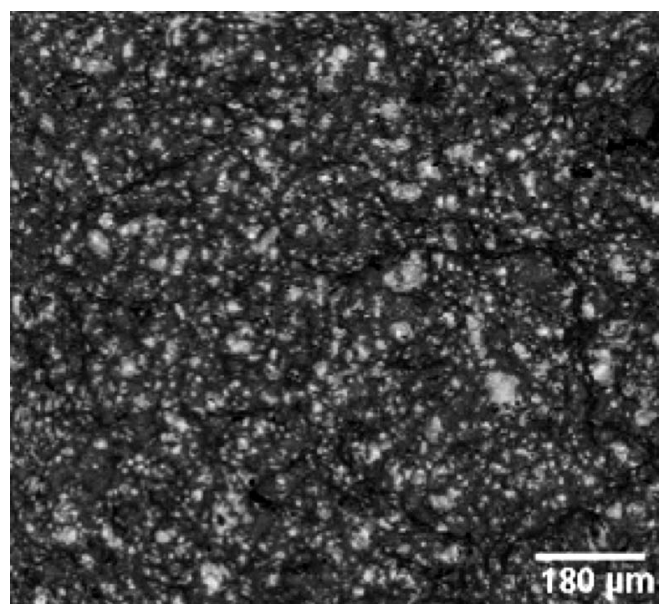

Figure 9. Fractography using SEM with backscattering at 200x, bright points indicate presence of lead.

Figura 9. Fractografía usando MEB con backscattering a 200x, puntos claros indican la presencia de plomo.

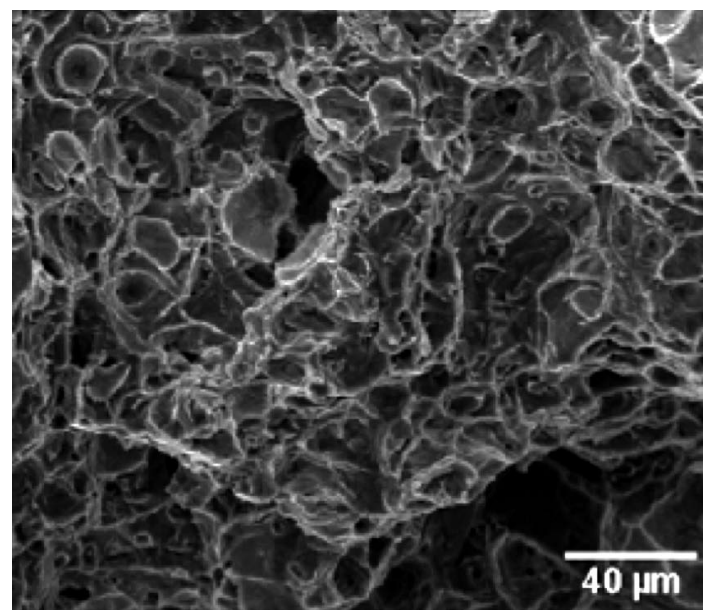

Figure 10. Fractography using SEM with secondary electrons at $1000 x$.

Figura 10. Fractografía usando MEB con electrones secundarios a 1000x. 


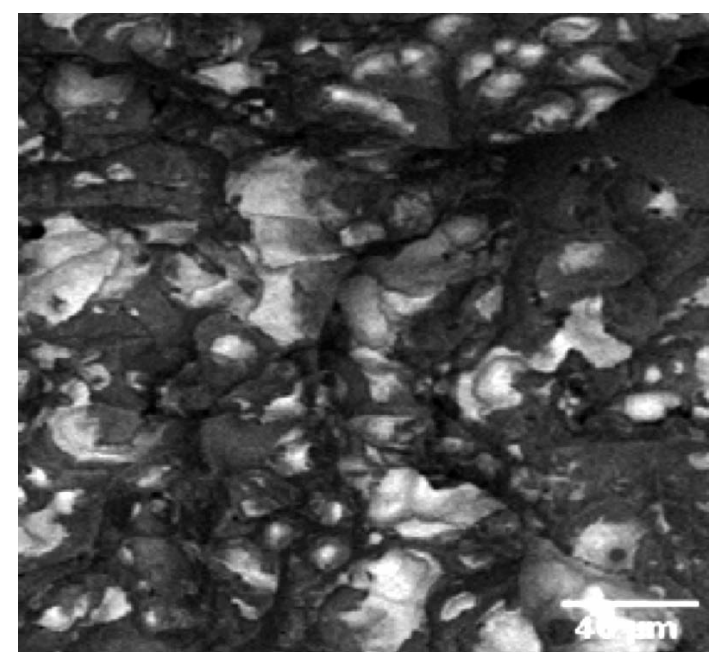

Figure 11. Fractography using SEM with backscattering at $1000 \mathrm{x}$, bright points indicate presence of lead.

Figura 11. Fractografía usando MEB con backscattering a 1000x, puntos claros indican la presencia de plomo.

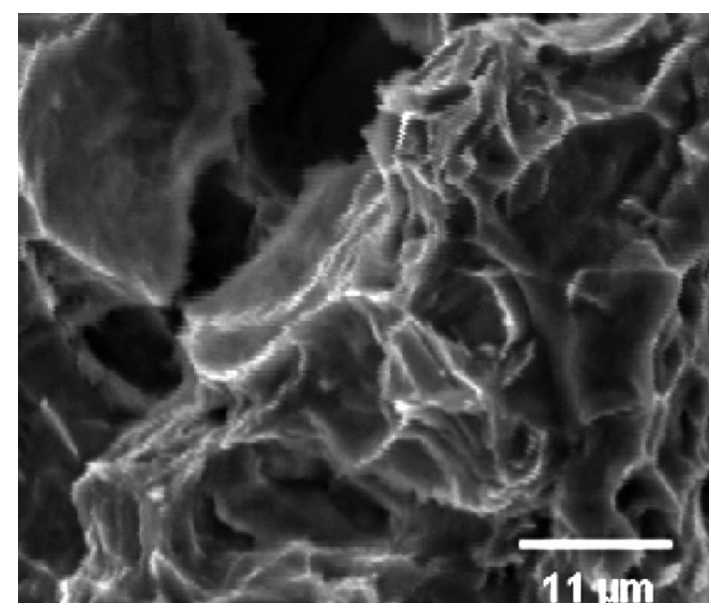

Figure 12. Fractography using SEM with secondary electrons at $3500 x$.

Figura 12. Fractografía usando MEB con electrones secundarios a 3500x.

the $101 \mathrm{~mm}$ rod. The extreme concentration of the lead can be appreciated in figure 13 with BEI, which is confirmed in an $\mathrm{x}$-ray analysis (EDS), figure 14 .

\section{DISCUSSION}

Fragile intergranular factures are very common in the case of failure in service, but are less frequent

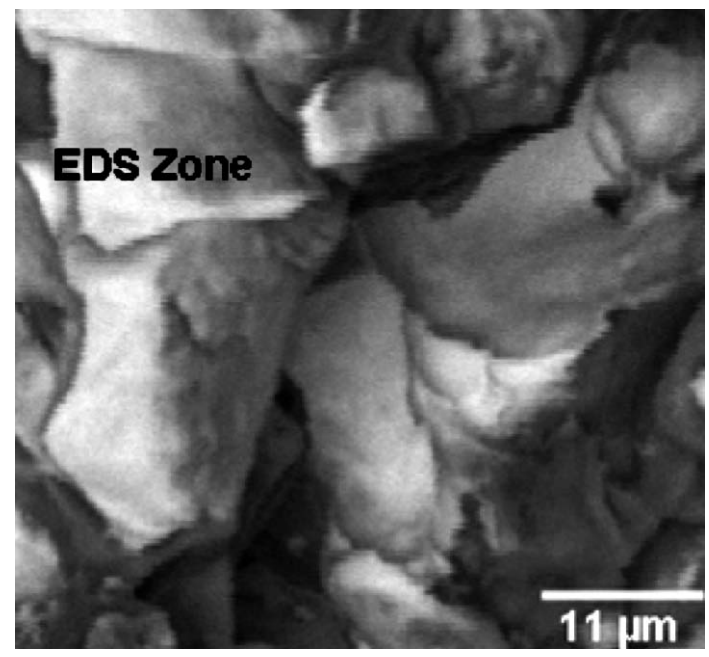

Figure 13. Fractography using SEM with backscattering at $3500 x$, bright points show the lead condensation.

Figura 13. Fractografía usando MEB con backscattering a 3500x, puntos claros muestran la condensación de plomo.

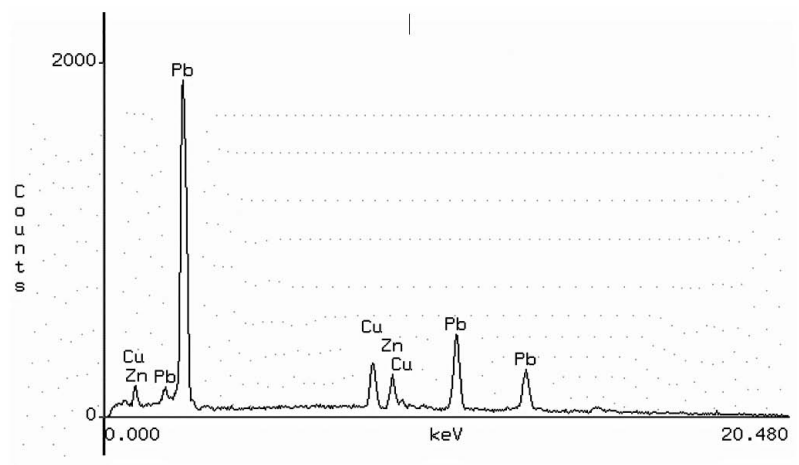

Figure 14. Dispersive energy spectrum of the white areas in the figure 13.

Figura 14. Espectro energía dispersiva de las áreas blancas de la figura 13.

after the extrusion process. On the other hand, in the cases of direct -because of very low extrusion (thick sections) - there is the risk of a "back end defect", which is produced preferentially in materials that flow in accordance to a $\mathrm{C}$ type; where the acceleration of the material in the center of billet can produce a funnel at the end of the extrusion. This type of failure should not be confused with the case under study in this work.

The present failure occurs in the hot extrusion process and, most probably is related to hot shortness, 
which appears in the last phase of solidification, in the temperature range close to the solidus line. The causes of this failure in the rod are a consequence of an insufficient capacity of the material to absorb tensions; given that the contraction of volume in solidification is blocked owing to the influence of heterogeneous cooling conditions in different areas of the rod. In figure 1 it can be seen that the failure is concentrated in the upper area of extruded rod, that is, in the area where cooling is the slowest.

In the failure analyzed in the present work, hot tearing is caused by chemical segregation (Figs. 9, 11,13 and 14) as a product of the high temperature in the extrusion process. Because of this, the dierod contact time in this alloy should be sufficiently brief to avoid heating over the limit of 500 to $600{ }^{\circ} \mathrm{C}$. In fact, the larger the ram speed, the smaller the heat transmitted to the die. For the rod under study, the extrusion temperature was 720 to $730^{\circ} \mathrm{C}$. Considering that tension is the main factor causing hot tearing, this can be generated by the longitudinal tensions during the extrusion processes (Fig. 5).

In the phenomena of hot shortness, an important role can be played by the joint effect of the extrusion ram speed (which was $17 \mathrm{~mm} / \mathrm{sec}$ for this $101 \mathrm{~mm}$ rod) and the temperature of the billet to be extruded. For its part, flow stress of the material is temperature sensitive and, hence, for a given extrusion ratio the lowest temperature limit is determined by the maximum press load, while the highest limit is defined by the observed hot-shortness phenomena. On the other hand, the need for the extrusion ram speed to be as high as possible and the billet temperature to be as low as possible is not only for economic motives. The methodology that was followed for optimization of these figures is based upon both basic concept of the extrusion process and experimental trial and error probes. Obviously, under such conditions production will be greater and the thermal stress on equipment will be briefer during the extrusion process. Hence, the find conditions where effectively concluded after systematic investigation, i.e. temperature and ram speed were varied until disappearance of the failure. The extrusion operating window was between 36 to $42 \mathrm{~mm} / \mathrm{s}$ for the ram speed and extrusion temperature range of $660-680^{\circ} \mathrm{C}$. Given the aforementioned, the material will cool less in contact with the container during the extrusion process due to heat conduction, resulting in a more uniform final temperature and microstructure throughout the extrusion process. Normally, the extrusion temperature and the deformation temperature are so high that the extruded section will be totally recrystalized, usually with a fine grain microstructure.
Nevertheless, it is possible to have microstructural variation between the beginning and end of the extrusion. Undoubtedly, upon the beginning of extrusion, there is less deformation in the middle and final parts.

The process of hot tearing can be separated in several stages:

- The process of deformation associated with each stage of solidification reaches a particular state in which a bath film separates in dendrites from the others (see figures 11 and 13). In this case, the morphology of solidification plays a fundamental role and the fissuring is favored by rough exogenous columnar microstructures (see figures 4 and 5).

- Once the first crack is formed, it can grow through a grooving effect with the concentration of force as a product of heterogeneous cooling.

- A filled crack can appear again (secondary cracks), because the remaining liquid can segregate and reduce the resistance of the film ${ }^{[5]}$.

\section{CONCLUSIONS}

Based upon the experimental results the followings concluding remarks can be pointed out:

The fractured $101 \mathrm{~mm}$ extruded rod was observed to have a strong concentration of tearing in the upper part of the rod, which is the area of higher temperature.

With low resolution it is possible to appreciate the tears that are found in a parallel direction to the extrusion. As a result of these cavities, the material does not have the property of air/water-tightness.

From the micro- fractographs taken with BEI, it can be concluded that this defect is the product of uni-axial tensions in a weak material, that is to say, that there is an elevated concentration of lead in the inter-critical area.

The strong thermal imbalance in the rod favors the aforementioned effect. This leads to the conclusion that we are dealing with a typical failure of hot shortness. Nevertheless, it is necessary to emphasize that we should not confuse the failure under study with that of dead metal, which is produced in the extrusion process with a direct extrusion press.

The factors that affect the failure are principally a 
very high temperature of the billet $720-730{ }^{\circ} \mathrm{C}$, a low extrusion ratio $4.1 / 1$ and a very low extrusion ram speed $17 \mathrm{~mm} / \mathrm{s}$. To avoid this effect the temperature of the billet could be lowered to 680 $690^{\circ} \mathrm{C}$ and the extrusion ram speed increased to $40 \mathrm{~mm} / \mathrm{s}$.

Upon lowering the initial temperature of the billet with this increase in extrusion ram speed, hot shortness can be avoided by shortening the contact time between the die and the extruded rod.

Given that hot tearing can induce a catastrophic failure, control is recommended for the production of all rods over $65 \mathrm{~mm}$ in diameter.

\section{Acknowledgements}

Support for this work was provided by Universidad de Santiago de Chile (USACH) and FONDECYT Project № 1070203 entitled "Comparison of bars of brass of extrusion direct-indirect and continuous casting in forging". The authors greatly appreciate this assistance, as well as experimental assistance given by Ms. Gladys Olivares and Mr. Felipe Gutierrez.

\section{REFERENCES}

[1] G. Pantazopoulos and A. Vazdirvanidis, J. Fail. Anal. Prevent. 8 (2008) 218-222.

[2] G. Pantazopoulos, J. Fail. Anal. Prevent 4 (2003) 14-22. 